\title{
Penggunaan Tepung Sagu (Metroxylon sp.) sebagai Bahan Baku Kukis Cokelat
}

\author{
The use of sago (Metroxylon sp.) flour as the ingredient of chocolate cookies
}

\author{
Susi Heryani dan Rhoito Frista Silitonga \\ Balai Besar Industri Agro \\ Jl. Ir. H. Juanda No. 11 Bogor, 16122 \\ ssheryani@yahoo.com
}

\section{Riwayat Naskah:}

Diterima 10, 2017

Direvisi 11,2017

Disetujui 12, 2017

\begin{abstract}
ABSTRAK: Tanaman sagu banyak tumbuh di berbagai wilayah di Indonesia, dan sangat potensial untuk dikembangkan sebagai bahan pangan alternatif. Pengembangan penggunaan sagu sebagai bahan pangan lain diperlukan untuk memberikan nilai tambah pada komoditi ini. Penelitian kali ini dilakukan pembuatan kukis cokelat menggunakan tepung sagu (Metroxylon sp.) dan dibandingkan dengan kukis cokelat menggunakan tepung terigu, lalu dilakukan uji organoleptik. Parameter uji organoleptik yang dilakukan yaitu warna, aroma, rasa, dan tekstur. Kadar air produk kukis cokelat menggunakan tepung terigu adalah 4,75\%, lebih besar dibanding produk kukis cokelat menggunakan tepung sagu (Metroxylon sp.) (4\%). Secara keseluruhan, baik untuk parameter warna, aroma, rasa dan tekstur, rata-rata panelis memberikan penilaian kesukaan yang lebih tinggi kepada produk kukis cokelat dari tepung sagu (Metroxylon sp.) dibandingkan dengan produk kukis dari tepung terigu.
\end{abstract}

Kata kunci: sagu, kukis, organoleptik

ABSTRACT: Sago plants grow in many areas in Indonesia, and very potential to be developed as an alternative food. The development of sago for food ingredients is needed to increase the value added of this commodity. This study was conducted to make a chocolate cookies using sago (Metroxylon sp.) and compared with chocolate cookies using wheat flour, by organoleptic test. The organoleptic test parameters are color, aroma, taste, and texture. Water content of chocolate cookies using wheat flour is $4,75 \%$, greater than chocolate cookies using sago (Metroxylon sp.) (4\%). Overall, for both color, aroma, taste and texture, the average panelist gives a higher preferential rating to the cookies products of the sago (Metroxylon sp.), compared to the wheat flour.

Keywords: sago, cookies, organoleptic

\section{Pendahuluan}

Tanaman sagu banyak tumbuh di berbagai wilayah di Indonesia, seperti Papua, Sulawesi, Maluku, Riau, dan Kalimantan. Oleh karena itu tanaman sagu sangat potensial untuk dikembangkan sebagai bahan pangan alternatif. Tanaman sagu bahkan dapat digunakan sebagai bahan dasar pembuatan beras analog (Yanica I.A 2013). Di Indonesia, penggunaan tepung sagu sebagai bahan pangan telah banyak dikenal dalam berbagai bentuk produk, diantaranya papeda, sagu lempeng, sagu tutupala, sagu uha, sinoli, bagea, dan sebagainya. Dalam industri pangan, tepung sagu juga telah digunakan sebagai bahan campuran produk mie (Setyabudi 2013), soun, roti, dan bakso. Tanaman sagu terbukti memiliki kandungan kalori yang tidak kalah dibanding dengan bahan pangan lainnya (Tabel 1) (Tekpan Unimus Web site 2006).

Tabel 1

Komposisi bahan pati sagu, tapioka dan pati garut setiap $100 \mathrm{~g}$

\begin{tabular}{|c|c|c|c|}
\hline Komponen & Tapioka & Pati Garut & $\begin{array}{l}\text { Pati } \\
\text { Sagu }\end{array}$ \\
\hline Kalori (kal) & 362 & 355 & 353 \\
\hline Protein ( g ) & 0,5 & 0,7 & 0,7 \\
\hline Lemak (g) & 0,3 & 0,2 & 0,2 \\
\hline Karbohidrat (g) & 86,9 & 85,2 & 84,7 \\
\hline Air (g) & 12.0 & 13,6 & 14,0 \\
\hline Fosfor (mg) & - & 22 & 13 \\
\hline Kalsium (mg) & - & 8 & 11 \\
\hline Besi (mg) & - & 1,5 & 1,5 \\
\hline
\end{tabular}

Sumber: http://tekpan.unimus.ac.id/wp-

content/uploads/2013/07/SAGU-SEBAGAI-BAHAN-PANGAN 
Berdasarkan Tabel 1 terlihat bahwa komposisi terbesar dari pati sagu adalah karbohidrat. Kandungan karbohidrat pada pati sagu tersebut hampir sama dengan kandungan karbohidrat dari berbagai jenis sagu asal Maluku, seperti Sagu Tuni, Ihur, Molat, Makanaru, dan Duri Rotan (Huwae 2014). Dari aspek nilai gizi, sagu mempunyai beberapa kelebihan dibanding tepung dari tanaman umbi atau serelia, karena mengandung pati tidak tercerna yang penting bagi kesehatan (Triwiyono B 2014).

Berbagai keunggulan sagu, seharusnya mampu menggerakkan peneliti lokal untuk mengembangkan keragaman produk pangan bernilai tambah tinggi yang berbasis sagu. Tidak hanya di pasar domestik, melainkan mencari nilai tambah di pasar internasional. Dengan asupan teknologi tepat guna yang didukung kontinuitas pasokan tepung sagu, keuntungan dari agroindustri sagu di pastikan akan terus membesar untuk masa mendatang (Jong \& Widjono 2007).

Selain sebagai bahan untuk membuat mie, soun, maupun roti, sagu dapat dimanfaatkan sebagai bahan untuk membuat kue kering, biskuit, kerupuk, kue basah dan lain-lain. Produk makanan ringan yang potensial baik dari segi proses produksi maupun pemasaran antara lain adalah kukis. Beberapa penelitian mengenai kukis yang dibuat dengan substitusi tepung lokal selain terigu diantaranya adalah kukis dari tepung mokaf, kukis dari tepung tempe dan kukis dari tepung labu (Agustin Y 2010; Cookpad website 2017; Santiko A 2008; Tabloid Sinar Tani Web site 2014).

Pada penelitian ini dilakukan pembuatan kukis cokelat dengan menggunakan tepung sagu (Metroxylon sp.) dan tepung terigu. Tujuan penelitian ini adalah untuk membandingkan kukis cokelat dari sagu (Metroxylon sp.) dengan kukis cokelat dari tepung terigu yang dapat diterima dan disukai panelis dengan syarat mutu sesuai SNI biskuit (SNI 2973:2011). Pengembangan formulasi kukis menggunakan tepung sagu (Metroxylon sp.) diharapkan dapat meningkatkan diversifikasi produk tersebut di tingkat Industri Kecil dan Menengah.

\section{Bahan dan Metode}

\subsection{Bahan}

Bahan baku yang digunakan meliputi sagu (Metroxylon sp.) asal Riau dan tepung terigu. Bahan penolong yang digunakan adalah telur, minyak nabati, gula pasir, coklat bubuk, pasta coklat, vanili dan soda kue.

\subsection{Persiapan bahan baku}

Dalam membuat produk kukis, salah satu proses pengolahan yang sangat berpengaruh terhadap hasil produk akhir adalah proses penyangraian tepung. Proses penyangraian merupakan perlakuan yang diberikan pada tepung sagu dan tepung terigu, yang bertujuan untuk mengurangi kadar air dan gluten. Kadar gluten tinggi akan menyebabkan adonan liat dan sulit dibentuk sehingga menghasilkan kukis yang tidak renyah dan keras. Menurut Reilly (1985) modifikasi perlakuan pada pati dapat dilakukan untuk mendapatkan sifat yang lebih baik dari sifat sebelumnya, atau mengubah beberapa sifat lainnya. Perlakuan ini dapat mencakup penggunaan asam, alkali, zat pengoksidasi, bahan kimia dan penggunaan panas yang akan menghasilkan gugus kimia baru dan perubahan bentuk, ukuran serta molekul pati.

\subsection{Pembuatan produk kukis cokelat}

Dalam membuat kukis, diperlukan formula produk yang menghasilkan produk akhir yang diterima oleh panelis. Selain itu proses pengolahan yang sama juga diperlukan untuk menghasilkan produk akhir dengan kualitas mutu yang baik dan seragam. Metode pembuatan produk kukis dapat dilihat pada Gambar 1 .

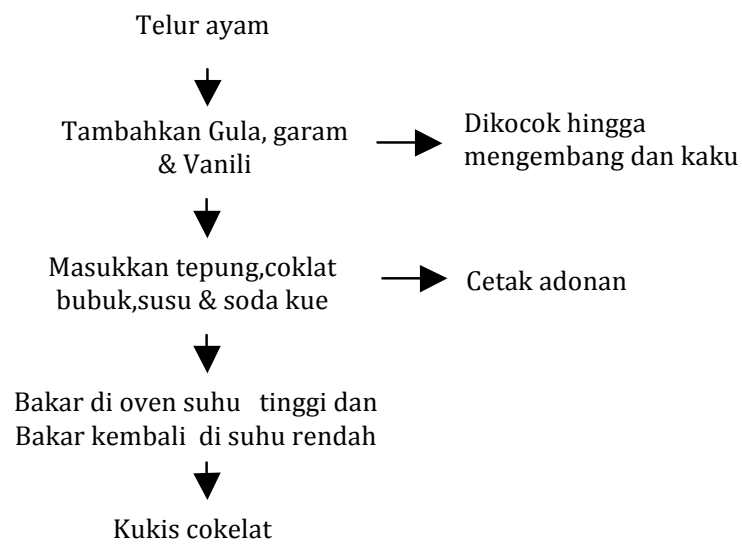

Gambar 1. Diagram Alir Proses Pembuatan Kukis (Puspitawulan, 1997)

\subsection{Metode}

Produk kukis cokelat dari sagu (Metroxylon $s p$.) dan produk kukis cokelat dari tepung terigu dilakukan uji organoleptik yaitu uji kesukaan.

Analisa yang dilakukan terhadap bahan baku terdiri dari pengujian kadar air , sedangkan analisa yang dilakukan terhadap produk kukis cokelat terdiri dari penambahan uji organoleptik berupa uji kesukaan warna aroma, rasa dan tekstur. 
Uji kesukaan dilakukan terhadap 20 orang panelis dengan skala penilaian kesukaan 1 (sangat tidak suka), 2 ( tidak suka), 3 ( cukup suka), 4 ( suka) dan 5 (sangat suka). Dalam penelitian ini, penulis menggunakan uji kesukaan yang merupakan bagian dari uji organoleptik. Menurut Sofiah dan Achsyar (2008), uji kesukaan atau uji hedonik merupakan uji dimana panelis diminta memberi tanggapan secara pribadi tentang kesukaan atau ketidaksukaan beserta tingkatannya.

\section{Hasil dan Pembahasan}

Pada pengolahan kukis ada beberapa faktor yang perlu diperhatikan yaitu penggunaan bahan penolong yang berfungsi untuk melembutkan, terdiri dari gula bubuk, shortening, kuning telur dan pengembang, serta bahan utama yang membentuk adonan, yang terdiri dari tepung, air dan putih telur atau seluruh telur. Pada penelitian ini formula yang digunakan dalam pembuatan kukis terdiri atas telur ayam negeri 350 gram, gula pasir 350 gram, garam 1 gram, bubuk vanili 1 gram, tepung terigu /sagu (Metroxylon sp.) 300 gram, coklat bubuk 5 gram, susu bubuk 8 gram, soda kue 1 gram, dan minyak sayur 330 gram.

Hasil pembuatan produk kukis cokelat menggunakan bahan baku sagu (Metroxylon sp.) dan bahan baku tepung terigu dapat dilihat pada Gambar 2.
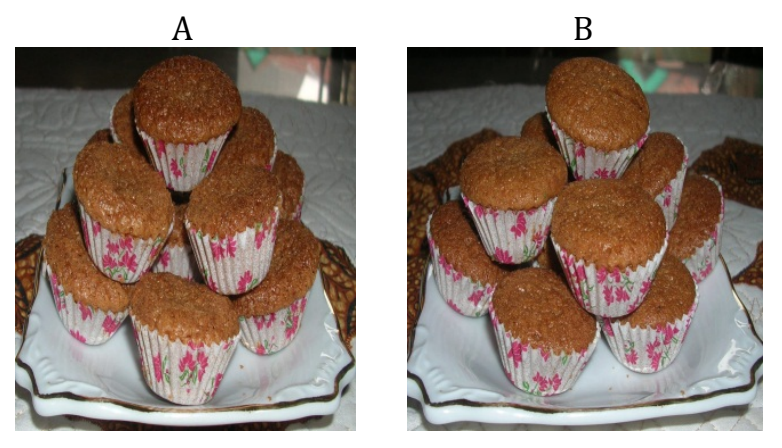

Gambar 2. Kukis cokelat dari sagu (Metroxylon sp.) (A) dan Kukis cokelat dari tepung terigu (B)

Hasil analisis kadar air produk kukis cokelat tersaji pada Tabel 2 .

Tabel 2

Hasil analisis kadar air terhadap kukis cokelat dari sagu (Metroxylon sp.) dan kukis cokelat dari tepung terigu

\begin{tabular}{cccc}
\hline No & Jenis Produk & $\begin{array}{c}\text { Kadar Air } \\
\text { (\%) }\end{array}$ & $\begin{array}{c}\text { SNI 2973- } \\
\mathbf{2 0 1 1} \\
\text { (Biskuit) }\end{array}$ \\
\hline 1 & $\begin{array}{c}\text { Kukis cokelat dari } \\
\text { sagu (Metroxylon sp.) }\end{array}$ & $4 \%$ & $\max 5 \%$ \\
\hline 2 & $\begin{array}{c}\text { Kukis cokelat dari } \\
\text { tepung terigu }\end{array}$ & $4,75 \%$ & $\max 5 \%$ \\
\hline
\end{tabular}

Hasil analisis kadar air terhadap produk kukis cokelat dari bahan baku sagu (Metroxylon sp.) kadar airnya $4 \%$ sedangkan kukis cokelat dari bahan baku terigu berkadar air 4,75\%, dengan perlakuan yang sama yaitu proses pemanggangan suhu $150^{\circ} \mathrm{C}$. Kukis cokelat dengan bahan baku sagu teksturnya lebih renyah bila dibandingkan dengan kukis cokelat dari bahan baku terigu. Hal ini diperkuat dengan kandungan kadar airnya yang lebih kecil. Semakin kecil kadar air pada suatu produk maka akan menghasilkan produk yang lebih renyah.

Kedua produk kukis cokelat tersebut kemudian dilakukan uji organoleptik berupa uji kesukaan. Uji organoleptik atau uji indera atau sensori, yang mempunyai peranan penting dalam penerapan mutu produk. Dalam penilaian bahan pangan, sifat yang menentukan diterima atau tidaknya suatu produk adalah sifat indrawinya (Wahyuningtias 2010).

Hasil penilaian uji organoleptik kemudian dikumpulkan dan dimasukkan kedalam tabel untuk dihitung persentase dan nila rata-ratanya. Hasil uji organoleptik untuk parameter warna, aroma, rasa, dan tekstur, masing-masing dapat dilihat pada Tabel 3 sampai dengan Tabel 6.

Tabel 3

Hasil penilaian uji organoleptik parameter warna

\begin{tabular}{ccccc}
\hline Produk & Nilai & $\begin{array}{c}\text { Jumlah } \\
\text { Panelis }\end{array}$ & $\begin{array}{c}\text { Persentas } \\
\text { e (\%) }\end{array}$ & $\begin{array}{c}\text { Nilai } \\
\text { rata - } \\
\text { rata }\end{array}$ \\
\hline Kukis cokelat & 2 & - & - & \\
dari sagu & 3 & - & - & \\
(Metroxylon $s p)$. & 4 & 8 & - & 4.60 \\
& 5 & 12 & 60 & \\
\hline Kukis cokelat & 1 & - & - & \\
dari tepung & 2 & 1 & 5 & \\
terigu & 3 & 7 & 35 & 3.55 \\
& 4 & 12 & 60 & \\
\hline
\end{tabular}

Berdasarkan Tabel 3 terlihat bahwa untuk parameter warna, panelis sangat suka dengan produk kukis dari sagu (Metroxylon sp.) (nilai 4.6), sedangkan produk kukis dari tepung terigu panelis merasa suka (nilai 3.5).

Tabel 4

Hasil penilaian uji organoleptik parameter aroma

\begin{tabular}{ccccc}
\hline Produk & Nilai & $\begin{array}{c}\text { Jumlah } \\
\text { Panelis }\end{array}$ & $\begin{array}{c}\text { Persent } \\
\text { ase (\%) }\end{array}$ & $\begin{array}{c}\text { Nilai } \\
\text { rata - } \\
\text { rata }\end{array}$ \\
\hline Kukis cokelat dari & 2 & - & - & \\
sagu (Metroxylon & 3 & 2 & - & \\
sp.) & 4 & 8 & 40 & \\
& 5 & 10 & 50 & \\
\hline Kukis cokelat dari & 2 & - & - & \\
tepung terigu & 3 & 7 & 5 & 3.60 \\
& 4 & 11 & 55 & \\
\hline
\end{tabular}


Berdasarkan Tabel 4 terlihat bahwa untuk parameter aroma, baik produk kukis cokelat dari sagu (Metroxylon sp.) maupun produk kukis cokelat dari tepung terigu, rata-rata panelis merasa suka, walaupun nilai rata-rata aroma produk kukis cokelat dari sagu (Metroxylon sp.) lebih tinggi dari pada produk kukis cokelat dari tepung terigu.

Tabel 5

Hasil penilaian uji organoleptik parameter rasa

\begin{tabular}{ccccc}
\hline Produk & Nilai & $\begin{array}{c}\text { Jumlah } \\
\text { Panelis }\end{array}$ & $\begin{array}{c}\text { Persentase } \\
\text { (\%) }\end{array}$ & $\begin{array}{c}\text { Nilai } \\
\text { rata - } \\
\text { rata }\end{array}$ \\
\hline Kukis cokelat & 1 & - & - & \\
dari sagu & 3 & - & - & \\
(Metroxylon sp.) & 4 & - & - & 4.75 \\
& 5 & 15 & 25 & \\
\hline Kukis cokelat & 1 & - & 75 & \\
dari tepung & 3 & - & - & \\
terigu & 4 & 2 & 10 & 3.95 \\
& 5 & 17 & 85 & \\
\hline
\end{tabular}

Berdasarkan Tabel 5 terlihat bahwa untuk parameter rasa, rata-rata panelis memberi hasil sangat suka terhadap produk kukis cokelat dari sagu (Metroxylon sp.) (nilai 4.75), sedangkan produk kukis cokelat dari tepung terigu, rata-rata panelis memberi hasil suka (nilai 3.95)

Tabel 6

Hasil penilaian uji organoleptik parameter tekstur

\begin{tabular}{ccccc}
\hline Produk & Nilai & $\begin{array}{c}\text { Jumlah } \\
\text { Panelis }\end{array}$ & $\begin{array}{c}\text { Persentase } \\
\text { (\%) }\end{array}$ & $\begin{array}{c}\text { Nilai } \\
\text { rata - } \\
\text { rata }\end{array}$ \\
\hline Kukis cokelat & 2 & - & - & \\
dari sagu & 3 & - & - & 4.85 \\
(Metroxylon sp.) & 4 & 3 & - & \\
\hline Kukis cokelat & 5 & 17 & 15 & \\
dari tepung & 2 & - & - & \\
terigu & 3 & 4 & 60 & 2.60 \\
& 4 & 4 & 20 & \\
\hline
\end{tabular}

Berdasarkan Tabel 6 terlihat bahwa untuk parameter tekstur, rata-rata panelis sangat suka dengan produk kukis cokelat dari sagu (Metroxylon $s p$.) (nilai 4.85), dibandingkan dengan produk kukis cokelat dari tepung terigu yang hanya cukup suka saja (nilai 2.60).

Berdasarkan hasil organoleptik pada Tabel 3 sampai Tabel 6, terlihat bahwa penilaian kesukaan terhadap produk kukis cokelat dari sagu (Metroxylon $s p$.) memiliki nilai yang lebih baik dibanding produk kukis cokelat dari tepung terigu. Hal ini semakin menguatkan kembali mengenai penggunaan dan pengembangan sagu sebagai bahan pangan alternatif, dengan nilai tambah yang tinggi. Bila pemanfaatan sagu sebagai bahan pangan pokok lebih dikembangkan lagi, maka komoditas ini dapat digunakan untuk mengatasi masalah ketahanan pangan nasional(Jong \& Widjono 2007).

Penggunaan sagu sebagai sumber makanan baru ditandai juga dengan meningkatnya permintaan terhadap bahan pangan tersebut. Berdasarkan penelitian di Sulawesi Selatan, penjualan tepung sagu mengalami peningkatan signifikan pada Tahun 2006 - 2013, yaitu sekitar 25\% (Metaragakusuma et al. 2017). Penggunaan sagu sebagai alternatif bahan pangan juga telah dilakukan di beberapa negara lain seperti Malaysia, melalui penanaman lahan sagu untuk komersialisasi (Chew et al. 1998; Naim HM et al. 2016).

\section{Kesimpulan}

Berdasarkan hasil perbandingan uji organoleptik, dapat disimpulkan bahwa warna, aroma, rasa, dan tekstur dari produk kukis cokelat yang terbuat dari sagu (Metroxylon sp.) memiliki nilai yang lebih disukai dibandingkan dengan produk kukis cokelat yang terbuat dari tepung terigu. Oleh karena itu dapat disimpulkan bahwa sagu (Metroxylon sp.) dapat digunakan sebagai bahan baku kukis cokelat menggantikan tepung terigu.

\section{Ucapan Terima Kasih}

Penulis mengucapkan terimakasih kepada Balai Besar Industri Agro atas dana penelitian yang diberikan.

\section{Daftar Pustaka}

Chew, T., Hassan, A., Ghazah, M., \& Ghazah, I. (1998). The sago industry in Malaysia: present status and future prospects. Proceedings of the 7th International Working Conference on Stores-Product Protection, 2, 1720-1728.

Cookpad Web site. (2017). Retrieved September 10, 2017, from https://cookpad.com/id.

Huwae, B. R. (2014). Analisis Kadar Karbohidrat Tepung Beberapa Jenis Sagu Yang Dikonsumsi Masyarakat Maluku. Biopendix, 1(1), 59-64.

Jong, F. S., \& Widjono, D. A. (2007). Sagu: Potensi Besar Pertanian Indonesia. Iptek Tanaman Pangan, 2(1), 54-65.

Metaragakusuma., A. P., Osozawa., K., \& Hu, B. (2017). The Current Status of Sago Production in South Sulawesi : Its Market and Challenge as a New Food- Industry Source. International Journal Sustainable Future for Human Security, 5(1), 31-45.

Naim HM, Yaakub, A. N., \& Awang Hamdan, D. A. (2016). Commercialization of Sago through Estate Plantation Scheme in Sarawak: The Way Forward. International Journal of Agronomy, 2016. https://doi.org/10.1155/2016/8319542

Puspitawulan, A.M. (1997). Mempelajari Sorpsi Isotermi dan Kerenyahan Cookies pada Berbagai Kondisi Penyimpanan. Fakultas Teknologi Pertanian, Institut Pertanian Bogor, Bogor.

Rahayu, W.P. (2001).Penuntun Praktikum Penilaian Organoleptik. Teknologi Pangan dan Gizi. Bogor : Fakultas Teknologi Pertanian Institut Pertanian Bogor.

Reilly, P.J. 1985. Enzymeatic Degradation of Starch. Marcell 
Deccker Inc., New York

Santiko, A. (2008). Pengaruh Substitusi Tepung Terigu dengan Tepung Tempe dan Tepung Bekatul terhadap Kadar Protein, Kadar Serat dan Daya Terima Kue Kering Kayu Manis. Program Studi Ilmu Gizi Fakultas Kedokteran Universitas Diponegoro, Semarang.

Setyabudi, A. (2013). Pengembangan Mi Glosor Instan dari Tepung Sagu Aren dengan Substitusi Tepung Labu Kuning sebagai Alternatif untuk Diversifikasi Pangan. Retrieved from

http://repository.ipb.ac.id/handle/123456789/63412

Sofiah, B.D., Achyar, T.S. (2008). Buku Ajar Kuliah Penilaian Indra. Jatinangor : Universitas Padjajaran.

Tabloid Sinar Tani Web site. (2014). Kue Kering Berbahan Mocaf. Retrieved

from http://m.tabloidsinartani.com/index.php?id=148\&tx_ttne ws\%5Btt_news\%5D=1054\&cHash=71b6aa552663715016 b47dc9f9f 48111
Tekpan Unimus Web site. (2006). Retrieved December 5, 2017, from http://tekpan.unimus.ac.id/wpcontent/uploads/2013/07/SAGU-SEBAGAI-BAHANPANGAN.pdf

Triwiyono, B. (2014). Modifikasi Tepung Sagu dengan Cara Ekstrusi menjadi Sagu Flakes untuk Substitusi Tepung Terigu sebagai Bahan Baku Indsutri Pangan Olahan Kapasitas 1 Ton/Hari di Provisnsi Bangka Belitung dan Lampung. Balai Besar Teknologi Pati, Lampung.

Wahyuningtias, D., (2010). Uji Organoleptik Hasil Jadi Kue Menggunakan Bahan Non Instant Dan Instan, 1(9), 116125.

Yanica I.A. (2013). Indeks Glikemik dan Karakterisasi Kimia Beras Analog Berbahan Dasar Jagung, Sorgum, dan Sagu Aren. Institut Pertanian Bogor, Bogor. 